\title{
Analisis Determinan Pengungkapan Internet Financial Reporting pada Perusahaan Manufaktur yang terdaftar di Bursa Efek Indonesia
}

\author{
Tria Meinawati \\ Universitas Islam Batik Surakarta \\ triameinawati@gmail.com
}

\author{
Suhendro \\ Universitas Islam Batik Surakarta \\ ndro_s@yahoo.com
}

\author{
Endang Masitoh \\ Universitas Islam Batik Surakarta \\ yunmasitoh@yahoo.com
}

Corresponding Author : Tria Meinawati

Submitted: 23 Juni 2020

Accepted: 1 Agustus 2020

Published: 1 Agustus 2020

\section{ABSTRAK}

Internet Financial Reporting merupakan pelaporan keuangan melalui internet.Tujuan dari penelitian ini yaitu untuk menganalisis pengaruh dari Profitabilitas, Likuiditas, Ukuran Perusahaan, Umur \ Perusahaan dan Reputasi Auditor terhadap pengungkapan Internet Financial Reporting pada perusahaan Manufaktur di Indonesia. Populasi dalam penelitian ini yaitu seluruh perusahaan Manufaktur yang terdaftar di Bursa Efek Indonesia sampai dengan tahun 2018. Teknik pengambilan sampel dalam penelitian ini menggunakan metode Purposive Sampling dan diperoleh sampel sebanyak 89 perusahaan dengan periode pengamatan 2017-2018. Data sampel kemudian dianalisis menggunakan analisis regresi linear berganda menggunakan SPSS 22. Hasil dalam penelitian ini menunjukkan bahwa Profitabilitas, Ukuran Perusahaan, Umur Perusahaan dan Reputasi Auditor berpengaruh secara parsial terhadap pengungkapan Internet Financial Reporting. Sedangkan Likuiditas tidak berpengaruh secara parsial terhadap pengungkapan Internet Financial Reporting. Sedangkan secara simultan Profitabilitas, Likuiditas , Ukuran Perusahaan, Umur Perusahaan dan Reputasi Auditor secara bersama-sama mempunyai pengaruh terhadap pengungkapan Internet Financial Reporting.

Kata Kunci : Profitabilitas, Likuiditas, Ukuran Perusahaan, Umur Perusahaan, Reputasi Auditor, dan Internet Financial Reporting

\section{PENDAHULUAN}

1.1 Latar Belakang Masalah

Teknologi komunikasi dewasa ini mengalami perkembangan yang cukup signifikan. Dampak yang paling besar terlihat pada bidang ekonomi. Sekarang ini, kegiatan ekonomi dapat dijangkau secara global dengan media internet.

Internet hadir menawarkan suatu bentuk baru menjadi media dalam pengungkapan infomasi perusahaan kepada masyarakat luas yang dapat 
dilakukan dengan cepat. (Abdelsalam,et al., 2007). Salah satunya yaitu pengungkapan informasi

keuangan perusahaan yang biasa disebut Internet Financial Reporting. Internet

Financial Reporting dewasa ini kian banyak digunakan oleh perusahaanperusahaan Go-Public.

Menurut Widari, Saifi dan Nurlaily (2018), tiap-tiap perusahaan dalam suatu mempunyai tingkat pengungkapan yang berbeda-beda. Begitu pula di Indonesia, setiap perusahaan memiliki kebijakan dan aturan tersendiri dalam pelaksanaan Internet Financial Reporting.

Praktik IFR dilakukan sebagai suatu bentuk pertanggungjawaban perusahaan kepada stakeholders untuk memberikan informasi terkini perusahaan dalam rangka mengurangi tingkat informasi asimetri. Menurut keputusan Menteri Perindustrian dan Perdagangan Republik Indonesia Nomor : 121/MPP/Kep/2/2002 tentang Ketentuan Penyampaian Laporan Keuangan Tahunan Perusahaan ,yang berisi tentang kewajiban setiap perusahaan menyampaikan laporan keuangannya kepada pemerintaha dan laporan tersebut bersifat umum yang dapat diketahui masyarakat.

Pengungkapan IFR sekarang ini banyak dilakukan oleh perusahaanperusahaan publik di Indonesia selain efisiensi waktu dan tenaga, dengan memanfaatkan website perusahaan, pengungkapan IFR juga akan menekan agency cost. Menurut Peraturan Otoritas Jasa Keuangan (PJOK) No.8/POJK.04/2015 pasal 2 bahwasanya Emiten atau perusahaan publik wajib memiliki situs website. Perusahaan yang telah memiliki website resmi diharapkan dapat memanfaatkan dengan sebaik mungkin agar mampu menyampaikan laporan keuangannya sesuai dengan waktu yang telah ditetapkan.

Penelitian Muliati

menunjukan hasil jumlah perusahaan yang melaporkan informasi keuangannya di website masih kurang dari $50 \%$ jumlah perusahaan yang terdaftar di Bursa Efek Indonesia. Penelitian Putri (2013) menunjukkan hasil bahwa internet financial reporting index pada perusahaan-perusahaan besar berada dibawah rata-rata $56,75 \%$.

Sedangkan berdasarkan Notasi Khusus yang dikeluarkan oleh Bursa Efek Indonesia No : Peng-SPT00007/BEI.PP1/07 -2018, No : PengSPT-00007/BEI.PP2/07-2018, No : PengSPT-00008/BEI.PP3/07-2018 sampai dengan tanggal 29 juni 2018 masih ada 10 perusahaan yang belum menyampaikan Laporan Keuangan Auditan per 31 Desember 2017. (https://www.idx.co.id/perusahaantercatat/notasi-khusus/)

\subsection{Perumusan Masalah}

Dengan dasar uraian latar belakang diatas, maka perumusan masalah adalah sebagai berikut :

1. Bagaimana tingkat profitabilitas berpengaruh terhadap pengungkapan Internet Financial Reporting pada perusahaan Manufaktur yang terdaftar di BEI ?

2. Bagaimana tingkat likuiditas berpengaruh terhadap pengungkapan Internet Financial Reporting pada perusahaan Manufaktur yang terdaftar di BEI ?

3. Bagaimana ukuran perusahaan berpengaruh terhadap pengungkapan Internet Financial Reporting pada perusahaan Manufaktur yang terdaftar di BEI ?

4. Bagaimana umur perusahaan berpengaruh terhadap pengungkapan Internet Financial Reporting pada perusahaan Manufaktur yang terdaftar di BEI?

5. Bagaimana reputasi auditor berpengaruh terhadap pengungkapan Internet Financial Reporting pada 
perusahaan Manufaktur yang terdaftar di BEI?

\subsection{Tujuan Penelitian}

Berdasarkan rumusan masalah tersebut diatas, maka tujuan yang diharapkan pada penelitian ini adalah:

1. Untuk menguji dan menganalisis pengaruh tingkat profitabilitas terhadap pengungkapan Internet Financial Reporting pada perusahaan Manufaktur yang terdaftar di BEI.

2. Untuk menguji dan menganalisis pengaruh tingkat likuiditas terhadap pengungkapan Internet Financial Reporting pada perusahaan Manufaktur yang terdaftar di BEI.

3. Untuk menguji dan menganalisis pengaruh ukuran peruasahaan terhadap pengungkapan Internet Financial Reporting pada perusahaan Manufaktur yang terdaftar di BEI.

4. Untuk menguji dan menganalisis pengaruh umur peruasahaan terhadap pengungkapan Internet Financial Reporting pada perusahaan Manufaktur yang terdaftar di BEI.

5. Untuk menguji dan menganalisis pengaruh reputasi auditor terhadap pengungkapan Internet Financial Reporting pada perusahaan Manufaktur yang terdaftar di BEI.

\section{TINJAUAN PUSTAKA}

\subsection{Teori Signalling}

Signalling theory menjelaskan bahwa teori sinyal digunakan untuk mengurangi information asymmetry yang berkaitan dengan perusahaan pemberi informasi dan stakeholders. (Connelly, et al. 2011). Sinyal yang dimaksud dalam hal ini yaitu informasi perusahaan mencakupi informasi manajemen sampai dengan kegiatan keseharian perusahaan dalam rangka mewujudkan tujuan bersama

\subsection{Profitabilitas}

Profitabilitas digunakan sebagai parameter perusahaan dalam rangka menilai kemampuan yang dimiliki perusahaan dalam usahaanya untuk memperoleh laba dengan memanfaatkan dari sumber kekayaan yang dimiliki perusahaan (Sudana , 2011).

MenurutAly, Doaa, Simon dan Hussainey (2010), menyatakan bahwa profitabilitas berperngaruh pada kualitas Internet Financial Reporting. Bertambahnya nilai profitabilitas akan menambah nilai plus terhadap tata Kelola manajemen perusahaan, sehingga tingkat pengungkapan Internet Financial Reporting akan semakin tinggi.

\subsection{Likuiditas}

Dapat diartikan sebagai kemampuan suatu perusahaan dalam pemenuhan kewajiban jangka pendeknya. Kewajiban jangka pendek yang dimaksud yakni berupa membayar gaji karyawan, tagihan listrik dan air atau hutang yang telah jatuh tempo (Prasetya \& Irwandi , 2012).

Tingginya nilai likuiditas perusahaan cenderung akan mempengaruhi pengungkapan informasi secara lengkap dan lebih terinci karena kondisi perusahaan yang baik atau likuid.

\subsection{Ukuran Perusahaan}

Merupakan pengelompokkan perusahaan yang didasarkan pada total aktiva, dan nilai saham yang dimiliki perusahaan. (Prasetyorini, 2013). Fabiolla dan Bangun (2019) meyatakan jika ukuran pada sebuah perusahaan akan mempunyai pengaruh pada Internet Financial Reporting. Perusahaan besar akan memperhatikan tingkat pengungkapan

\subsection{Umur Perusahaan}

Menurut Poerwadarminta (2003), umur perusahaan adalah lama nya waktu 
hidup atau ada (sejak dilahirkan atau diadakan). Sedangkan secara umum umur perusahaan merupakan lamanya waktu perusahaan untuk hidup dan mempertahankan usahanya dan dapat bersaing dengan kompetitor. Perusahaan dengan usia hidup yang lebih lama, setidaknya memiliki profesionalitas yang lebih tinggi dibandingkan perusahaan baru.

Hasil Penelitian Maharani dan Kartika (2017), menyatakan jika umur perusahaan memiliki pengaruh positif signifikan terhadap Internet Financial Reporting. Livina, Vivien (2016), juga menyatakan bahwa umur perusahaan berpengaruh terhadap Internet Financial Reporting.

Semakin banyak pengalaman yang dimiliki suatu perusahaan maka akan semakin cakap dalam Teknik penyusunan dan pengungkapan laporan keuangan.

\subsection{Reputasi Auditor}

Adalah batas hidup suatu perusahaan dimulai dari perusahaan itu didirikan Poerwadarminta (2003). Secara umum dapat diartikan sebagai durasi waktu perusahaan untuk hidup dan mempertahankan usahanya dan dapat bersaing dengan kompetitor. Perusahaan dengan usia hidup yang lebih lama, setidaknya memiliki profesionalitas yang lebih tinggi dibandingkan perusahaan baru.

Hasil Penelitian Maharani dan Kartika (2017), menyatakan jika umur perusahaan berpengaruh pada proses pengungkapan Internet Financial Reporting. Makin lama suatu perusahaan berdiri, maka semakin luas pengalaman dan kemampuan yang dimiliki perusahaan.

Pemilihan Auditor yang tepat diharapkan akan menghasilkan hasil audit yang berkualitas, sehingga akan mendorong pengungkapan Internet Financial Reporting.

\subsection{Internet Financial Reporting}

Interne tFinancial Reporting (IFR) adalah penyampaian informasi keuangan perusahaan melalui internet pada website perusahaan dengan tujuan untuk mempererat hubungan baik dengan para investor, analisis, pemegan gsaham, ataupun para pengguna laporan keuangan yang lain (Yulianty,2011). Internet Financial Reporting menjadi salah satusolusidalam proses pengungkapan informasi keuangan perusahaan, hal ini dikarenakan Internet Financial Reporting mampu menekan dan menghemat biaya produksi dan distribusi informasi perusahaan.

\subsection{Kerangka Konseptual}

Berdasarkan uraian bab sebelumnya, maka dapat digambarkan kerangka konseptual sebagai berikut:

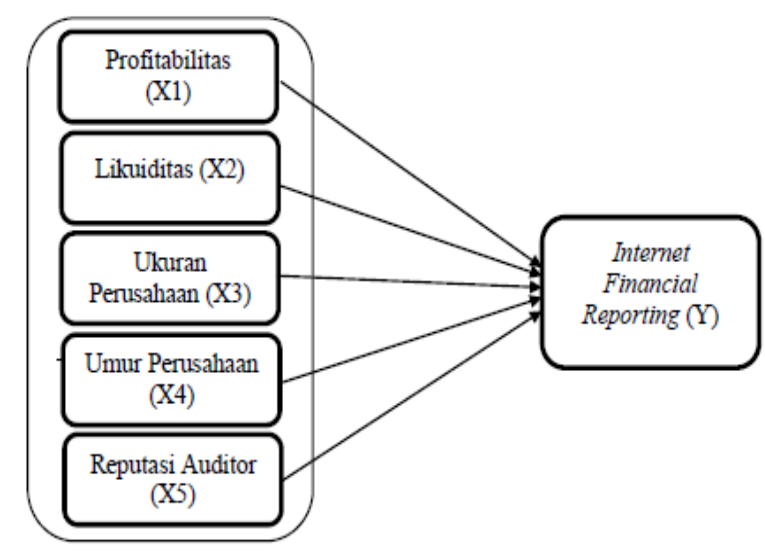

Gambar 1 kerangka konseptual

\section{METODE PENELITIAN}

\subsection{Populasi dan Sampel}

Populasi dalam penelitian ini adalah seluruh perusahaan Manufaktur yang terdaftar di Bursa Efek Indonesia sampai dengan tahun 2018. Periode pengamatan yaitu pada tahun 2018. Metode pemilihan sampel yaitu menggunakan metode purposive sampling yaitu Teknik 
pengambilan sampel dengan kriteria tertentu.

Tabel 1 Sampel Penelitian

\begin{tabular}{|c|c|c|}
\hline No & $\begin{array}{l}\text { Karakteristik } \\
\text { Perusahaan }\end{array}$ & Total \\
\hline 1 & $\begin{array}{l}\text { Perusahaan Manufaktur } \\
\text { yang terdaftar di Bursa } \\
\text { Efek Indonesia sampai } \\
\text { tahun } 2018\end{array}$ & 174 \\
\hline 2 & $\begin{array}{l}\text { Jumlah perusahaan yang } \\
\text { delisting sampai dengan } \\
\text { tahun } 2018\end{array}$ & (2) \\
\hline 3 & $\begin{array}{l}\text { Jumlah website } \\
\text { perusahaan yang tidak } \\
\text { dapat diakses }\end{array}$ & (7) \\
\hline 4 & $\begin{array}{l}\text { Jumlah perusahaan yang } \\
\text { tidak melaporkan laporan } \\
\text { keuangan periode tahun } \\
2018\end{array}$ & (17) \\
\hline 5 & $\begin{array}{l}\text { Jumlah perusahaan yang } \\
\text { tidak menyediakan } \\
\text { laporan keuangan dengan } \\
\text { satuan rupiah } \\
\end{array}$ & (27) \\
\hline 6 & $\begin{array}{l}\text { Jumlah perusahaan yang } \\
\text { mengalami kerugian }\end{array}$ & (32) \\
\hline 7 & $\begin{array}{l}\text { Jumlah Perusahaan } \\
\text { Manufaktur Yang tidak } \\
\text { menyediakan informasi } \\
\text { yang dibutuhkan. }\end{array}$ & (3) \\
\hline 8 & $\begin{array}{lr}\text { Jumlah Perusahaan } \\
\text { Manufaktur } & \text { Yang } \\
\text { Dijadikan Sampel. }\end{array}$ & 89 \\
\hline
\end{tabular}

Sumber : www.idx.co.id

Sampel yang digunakan dalam penelitian ini yaitu sebanyak 89 perusahaan. Dengan satu tahun periode pengamatan.

\subsection{TeknikPengumpulanData}

Penelitian ini menggunakan data sekunder dengan Teknik pengumpulan data :

a. Studi dokumentasi, yaitu pengumpulan data yang diperoleh dari laporan tahunan perusahaan manufaktur periode tahun 2018. b. Observasi pada website perusahaan juga dilakukan dengan mempelajari data-data yang diperlukan dalam penelitian.

c. Studi Pustaka, Teknik pengumpulan data yang diperlehdaribuku-buku, artikel dan penelitianterdahulu.

\subsection{Variabel dan Pengukuran Profitabilitas}

Dalam penelitian ini profitabilitas di ukur dengan Return On Asset (ROA). Rumus ROA menurut Fahmi (2013:137) adalah :

$$
\begin{aligned}
& \begin{array}{l}
\text { Return On Assets } \\
=\frac{\text { Laba Setelah Pajak }}{\text { Total Aktiva }}
\end{array}
\end{aligned}
$$

\section{Likuiditas}

Likuiditas dihitung menggunakan Current Ratio. Current Ratio menurut Pratomo, A. J. (2015) dengan rumus:

$$
\text { Current Ratio }=\frac{\text { Aktiva Lancar }}{\text { Utang Lancar }}
$$

\section{Ukuran Perusahaan}

Besar kecilnya suatu perusahaan yang dapat dilihat dari total aset yang dimiliki oleh perusahaan dengan perhitungan nilai logaritma total aktiva. Hartono (2015:254)

$$
\text { Firm Size = Ln Asset Total }
$$

\section{Umur Perusahaan}

Perusahaan yang sudah lama berdiri, kemungkinan sudah memiliki pengalaman yang banyak Gumanti (2000). Umur perusahaan dihitung sejak perusahaan itu berdiri sampai pada tahun penelitian dilakukan.

Umur Perusahaan $=$ Tahun Penelitian -

Tahun Berdiri

\section{Reputasi Auditor}

Dalam penelitian ini, perusahaan yang menggunakan KAP BigFour akan diberinilai dummy 1 sedangkan yang tidak 
berafiliasi dengan KAP BigFour diberinilai dummy 0. (Budiyanto dan Aditya, 215)

\section{Internet Financial Reporting}

Internet Financial Reporting dikatakan berkualitas jika mengungkapkan item-item yang sesuai dengan indeks Internet Financial Reporting, jika mengungkapkan item dari indeks Internet Financial Reporting diberi score 1 , jika tidak mengungkapkan akan diberi nilai 0. Dalam penelitian ini untuk mengungkapkan Internet Financial Reporting peneliti menggunakan Indeks Internet Financial Reporting dari Luciana \& Sasongko (2009). Indeks IFR tersebut meliputi :

\section{Isi LaporanKeuangan (Content)}

Isi laporan keuangan terdiri dari laporan Tahunan, laporan triwulan, informasi saham, penggunaan Bahasa, serta Format HTML dan PDF.

\section{Ketepatan Waktu (Timeliness)}

Penyampaian informasi terkini yang dilakukan peusahaan meliputi siaran pers, laporan triwulan terbaru, update harga saham, serta update informasi perusahaan lainnya.

\section{Technology}

Terdiri dari penggunaan media teknologi multimedia, download plugin, dan XBRL.

\section{User Support}

Dalam aspek user support terdiri dari beberapa komponen sarana dari website perusahaan yaitu FAQ, peta situs, situs pencari, konsistensi desain website, dan banyaknya klik untuk memperoleh laporan keuangan.

IV. HASILDANPEMBAHASAN

4.1 Uji AsumsiKlasik

4.1.1 Uji Normalitas
Uji normalitas digunakan untuk melihat apakah variabel residual memiliki distribusi normal. Cara mendeteksi uji normalitas yaitu dilakukan pengujian dengan melihat grafik P-Plot dan Uji Kolmogorov-Smirnov Test.

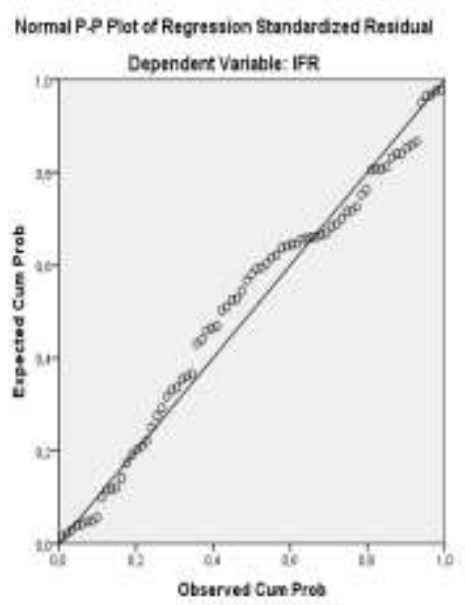

Gambar 1 Grafik P-Plot

Menurut grafik P-Plot diatas maka dapat disimpulkan jika data menyebar mengikuti garis diagonal sehingga model regregsi dinyatakan memenuhi asumsi normalitas.

Tabel 2 Hasil Uji Normalitas

\begin{tabular}{|l|l|r|}
\hline \multicolumn{2}{|c|}{$\begin{array}{c}\text { One-Sample Kolmogorov-Smirnov } \\
\text { Test }\end{array}$} \\
\hline \multicolumn{2}{|c|}{} & $\begin{array}{c}\text { Unstandardize } \\
\text { d Residual }\end{array}$ \\
\hline $\mathrm{N}$ & 77 \\
\hline $\begin{array}{l}\text { Normal } \\
\text { Parameters } \\
\text { b a, }\end{array}$ & $\begin{array}{l}\text { Mean } \\
\text { Std. } \\
\text { Deviatio } \\
\text { n }\end{array}$ & 4,0000000 \\
\hline $\begin{array}{l}\text { Most } \\
\text { Extreme } \\
\text { Differences }\end{array}$ & Absolute &, 089 \\
\cline { 2 - 3 } & Positive &, 061 \\
\hline Test Statistic &,- 089 \\
\hline Asymp. Sig. (2-tailed) &, 089 \\
\hline \multicolumn{2}{|l|}{ a. Test distribution is Normal. } \\
\hline \multicolumn{2}{|l|}{ b. Calculated from data. } \\
\hline
\end{tabular}

Hasil dari uji one sample kolmogrov smirnov menunjukkan jika nilai 
signifikansi sebesar 0,200 yaitu lebih besar dibandingkan dengan nilai standar sebesar 0,05. Jadi dapat disimpulkan jika data dalam penelitian ini terdistribusi secara normal.

\subsubsection{Uji Multikolinearitas}

Uji multikolinearitas dilakukan dengan melihat nilai Variance Inflance Faktor (VIF) dan nilai tolerance dari model regresi dari masing-masing variabel bebas. Hasil Uji multikolinearitas adalah sebagai berikut :

Tabel 3 Hasil Uji Multikolinearitas

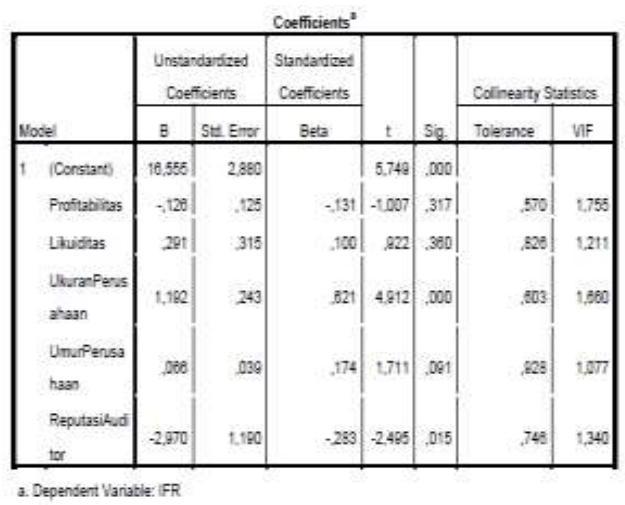

Menurut hasil pada tabel diatas, diketahui bahwa nilai VIF seluruh variabel bebas kurang dari 10 dan nilai tolerance lebih dari 0,1 . Sehingga dapat disimpulkan bahwa seluruh variabel bebas tidak mempunyai masalah dengan multikolinearitas.

\subsubsection{Uji Heteroskesdastisitas}

Untuk mendeteksi ada tidaknya heterokesdastisitas yaitu dapat dilihat dari grafik Scatterplot, jika titik-titik menyebar diatas maupun dibawah angka nol pada sumbu Y, maka dapat disimpulkan model regresi tidak mengandung heterokesdastisitas. Berikut gambar hasil uji heterokesdastisitas dalam bentuk grafikScatterplot:

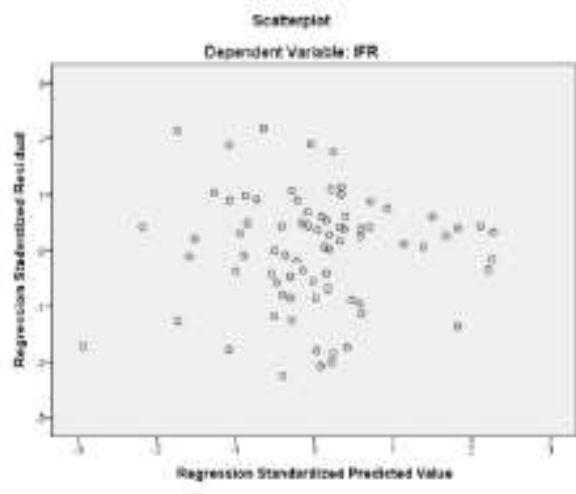

Gambar 2 GrafikScatterplot

Dari grafik Scatterplot dapat dilihat titik menyebar tanpa pola dan tersebar diatas maupun dibawah angka 0 pada sumbu Y, sehingga kesimpulannya tidak terjadi gejala heterokesdastisitas.

\subsubsection{Uji Autokorelasi}

Uji autokorelasi digunakan untuk menguji apakah dalam model regresi linear terdapat korelasi antara kesalahan penganggu pada periode $t$ dengan kesalahan pada periode t-1 (sebelumnya). Untuk mendiagnosis ada tidak nya korelasi dalam suatu model regresi maka dilakukan pengujian Durbin-Watson (DW test). Kriteria suatu model dinyatakan tidak terjadi autokorelasi, jika DU < DW < 4-DU, maka Ho diterima, artinya tidak terjadi autokorelasi. Berikuthasil uji autokorelasi :

\begin{tabular}{|c|c|c|c|c|c|}
\hline \multicolumn{6}{|c|}{ Tabel 4: Model Summaryb } \\
\hline Model & $\mathrm{R}$ & $\begin{array}{c}\mathrm{R} \\
\text { Square }\end{array}$ & $\begin{array}{l}\text { Adjusted } \\
\text { R } \\
\text { Square }\end{array}$ & $\begin{array}{c}\text { Std. } \\
\text { Error of } \\
\text { the } \\
\text { Estimate }\end{array}$ & $\begin{array}{l}\text { Durbin- } \\
\text { Watson }\end{array}$ \\
\hline 1 &, $563^{\mathrm{a}}$ & ,317 & ,269 & 4,22394 & 1,786 \\
\hline \multicolumn{6}{|c|}{$\begin{array}{l}\text { a. Predictors: (Constant), ReputasiAuditor, } \\
\text { LikuiditasKali, Profitabilitas, UmurPerusahaan, } \\
\text { UkuranPerusahaan }\end{array}$} \\
\hline b. Dep & endent & Variable & FR & & \\
\hline
\end{tabular}

Hasil Uji menyatakannilai DW sebesar 1,786. Dengan nilai N sebanyak 77 observasi dan jumlah variabel bebas sebanyak 5 variabel maka didapat nilai $\mathrm{dL}$ 
sebesar 1,4950 dan dU sebesar 1,7704. Dari hasil diatas dapat dibentuk persamaan $1,7704<1,7860<2,2296$. Dengan persamaan tersebut dapat disimpulkan jika nilai DW lebih besar dari nilai DU dan lebih kecil dari nilai 4-DU, sehingga dapat disimpulkan bahwa model regresi tidak terjadi autokorelasi.

\subsection{Koefisien Determinasi $\left(R^{2}\right)$}

Uji Koefisien determinasi merupakan suatu besaran yang digunakan untuk mengetahui kontribusi dari keseluruhan variabel bebas (independen) dapat menerangkan variabel terikat (dependen). Kisaran nilai koefisien determinasi diantara 0 sampai 1 . Semakin kecil nilai koefisien determinasi maka semakin kecil kemampuan variabel bebas menjelaskan variabel terikat, begitu juga sebaliknya (Ghozali, 2011). Hasil uji koefisiendeterminasiadalah:

Tabel 5 Hasil Uji Koefisien Determinasi

\begin{tabular}{|c|c|c|c|c|c|}
\hline \multicolumn{6}{|c|}{ Model Summary } \\
\hline Model & $\mathrm{R}$ & $\begin{array}{c}\mathrm{R} \\
\text { Square }\end{array}$ & $\begin{array}{l}\text { Adjusted } \\
\text { R Square }\end{array}$ & $\begin{array}{l}\text { Std. } \\
\text { Error of } \\
\text { the } \\
\text { Estimate }\end{array}$ & $\begin{array}{l}\text { Durbin- } \\
\text { Watson }\end{array}$ \\
\hline 1 &, $563^{\mathrm{a}}$ & ,317 & 269 & 4,22394 & 1,786 \\
\hline \multicolumn{6}{|c|}{$\begin{array}{l}\text { a. Predictors: (Constant), ReputasiAuditor, } \\
\text { LikuiditasKali, Profitabilitas, UmurPerusahaan, } \\
\text { UkuranPerusahaan }\end{array}$} \\
\hline b. Dep & dent & ariable & & & \\
\hline
\end{tabular}

Tabel di atas menunjukkan nilai $\mathrm{R}$ Square besarannya 0,317 menunjukkan bahwa proporsi pengaruh dari profitabilitas, likuiditas, ukuran perusahaan, umur perusahaan dan reputasi auditor terhadap Internet Financial Reporting sebesar $31,7 \%$. Dalam penelitian ini kemampuan variabel independen relatif rendah yaitu $31,7 \%$. Masih terdapat $(100 \%-31,7 \%=68,3 \%)$ varians variabel terikat yang belum mampu dijelaskan oleh kelima variabel bebas dalam model penelitian ini

\subsection{Model Penelitian}

IFR $=16,555-0,126 \mathrm{X} 1+0,291 \mathrm{X} 2+$ $1,192 X 3+0,066 X 4-2,970 \times 5$

1. Jika variabel lain dianggap konstan maka nilai Y/ Internet Financial Reporting meningkat sebesar 16,555.

2. Jika variabel X1/ profitabilitas dinaikkan 1 satuan, maka Internet Financial Reporting meningkat sebesar-0.126, dengan asumsivariabel lain independen lain nilainya konstan.

3. Jika variabel X2/ likuiditas dinaikkan 1satuan, maka Internet Financial Reporting meningkat sebesar 0,291, dengan asumsi variabel lain independen lain nilainya konstan.

4. Jika variabel X3/ ukuran perusahaand inaikkan 1satuan, maka Internet Financial Reporting meningkat sebesar 1,192, dengan asumsi variabel lain independen lain nilainya konstan.

5. Jika variabel $\mathrm{X} 4 /$ umur perusahaan 1satuan, maka Internet Financial Reporting meningkat sebesar0.066, dengan asumsi variabel lain independen lain nilainya konstan.

6. Jika variabel X5/reputasi auditor dinaikkan 1satuan, maka Internet Financial Reporting meningkat sebesar $-2,970$, dengan asumsi variabel lain independen lain nilainya konstan.

\subsection{Hasil Uji F}

Uji F menujukkan apakah suatu variabel bebas yang dimasukkan dalam model mempunyai pengaruh secara bersama-sama terhadap variabel dependen (Ghozali, 2006). Jika nilai signifikansi $\mathrm{F}$ lebih besar dari $\alpha=0,05$, maka variabel independen secara bersama-sama tidak mempunyai pengaruh yang signifikan terhadap variabel dependen. Hasil dapat dilihat pada tabel berikut:

Tabel 6 Hasil Uji F

\begin{tabular}{|l|c|c|c|c|c|}
\hline \multicolumn{6}{|c|}{ ANOVA $^{\mathbf{a}}$} \\
\hline Model & $\begin{array}{c}\text { Sum of } \\
\text { Squares }\end{array}$ & df & Mean & & \\
\hline
\end{tabular}




\begin{tabular}{|l|l|r|r|r|r|r|}
\hline 1 & $\begin{array}{l}\text { Regres } \\
\text { sion }\end{array}$ & 588,445 & 5 & $\begin{array}{r}117,68 \\
9\end{array}$ & 6,596 & $\begin{array}{r}000 \\
\mathrm{~b}\end{array}$ \\
\hline $\begin{array}{l}\text { Residu } \\
\text { al }\end{array}$ & 1266,75 & 71 & 17,842 & & \\
\hline Total & $\begin{array}{r}1855,20 \\
1\end{array}$ & 76 & & & \\
\hline
\end{tabular}

Berdasarkan data diatas terlihat bahwa nilai Sig pada tabel adalah 0,000 atau kurang dari 0,05. Maka dapat disimpulkan jika model penelitian diterima dan variabel independen secara simultan mempunyai pengaruh terhadap variabel dependen.

\subsection{Hasil Uji t}

Uji $t$ digunakan untuk mengetahui pengaruh masing-masing variabel independen terhadap variabel dependen. Jika nilai signifikansi nya lebih kecil dari 0,05 maka variabel independen tersebut berpengaruh signifikan terhadap variabel dependen. Hipotesis diterima jika nilai signifikansi $(\alpha)<0,05$ dan hipotesis ditolak jika tingkat signifikansi $(\alpha)>0,05$. Hasil pengujian dapat dilihat pada tabel berikut:

\section{Tabel 7 Hasil Uji t}

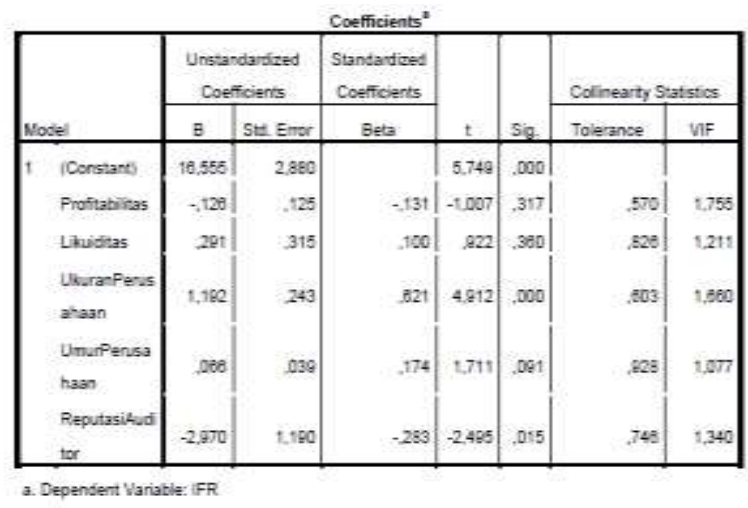

Berdasarkan tabel diatas dapat diketahui :

1. Nilai sig profitabilitas sebesar 0,317 lebih besar dari standar signifikansi $0,05(0,317>0,05)$, maka dapat disimpulkan bahwa profitabilitas tidak berpengaruh secara parsial terhadap Internet Financial Reporting.
2. Nilai sig likuiditas sebesar 0,360 lebih besar dari standar signifikansi 0,05 $(0,360>0,05)$, maka dapat disimpulkan bahwa likuiditas tidak berpengaruh secara parsial terhadap Internet Financial Reporting.

3. Nilai sig ukuran perusahaan sebesar 0,360 lebih kecil dari standar signifikansi $0,000(0,000<0,05)$, maka dapat disimpulkan bahwa ukuran peruasahaan berpengaruh secara parsial terhadap Internet Financial Reporting.

4. Nilai sig umur perusahaan sebesar 0,91 lebih besar dari standar signifikansi $0,05(0,091>0,05)$, maka dapat disimpulkan bahwa umur perusahaan tidak berpengaruh secara parsial terhadap Internet Financial Reporting.

5. Nilai sig reputasi auditor sebesar 0,015 lebih kecil dari standar signifikansi $0,05(0,015<0,05)$, maka dapat disimpulkan bahwa reputasi auditor berpengaruh secara parsial terhadap Internet Financial Reporting.

\section{PENUTUP}

\subsection{Kesimpulan}

Setalah dilakukan ujia dan analisis data, maka dapat disimpulkan hasil sebagai berikut :

1. Profitabilitas (ROA) tidak berpengaruh secara signifikan terhadap Internet Financial Reporting.

2. Likuiditas tidak berpengaruh secara signifikan terhadap Internet Financial Reporting.

3. Ukuran perusahaan memiliki pengaruh positif dan signifikan terhadap Internet Financial Reporting.

4. Umur perusahaan tidak berpengaruh secara signifikan terhadap Internet Financial Reporting.

5. Reputasi Auditor memiliki pengaruh yang signifikan terhadap Internet Financial Reporting. 


\subsection{KeterbatasanPenelitian}

1. Periode tahun pengamatan pada perusahaan Manufaktur hanya terbatas pada tahun 2018 saja

2. Adanya subjektifitas dalam pengukuran indeks Internet Financial Reporting pada website perusahaan, karena minimnya alat ukur yang diadaptasi dari penelitian Luciana \&Sasongko (2009).

\subsection{Saran}

Berdasarkan keterbatasan diatas, peneliti memberikan beberapamasukan yaitu :

1. Bagi peneliti-peneliti selanjutnya dengan lingkup tema yang sama, diharapkan dapat memperluas periode pengamatan dan menggunakan indeks pengungkapan sukarela lainnya seperti, indeks GIDI (Graphical Information Disclosure Index), atau indeks lainnya untuk hasil yang lebih baik lagi.

2. Bagi perusahaan, hasil penelitian ini diharapkan dapat menjadi evaluasi bagi perusahaan mengenai kekurangan yang terjadi dalam pengungkapan Internet Financial Report yang telah dilakukan.

\section{DAFTAR PUSTAKA}

Abdullah, M. D. F., Ardiansah, M. N., \& Hamidah, N. (2017). The Effect of Company Size, Company Age, Public Ownership and Audit Quality on Internet Financial Reporting. Sriwijaya International Journal of Dynamic Economics and Business, 1(2), 153-166.

Ade Rahma, A., Lusiana, L., \& Indriani, P. (2009). Pengaruh Struktur Modal, Profitabilitas dan Size Perusahaan Terhadap Ketepatan Waktu Pelaporan Keuangan Pada Perusahaan Manufaktur. Jurnal Benefita, 4(2), 210.
Alhajjriana, G. I., Nor, W., \& Wijaya, R. (2018). Faktor-Faktor yang Mempengaruhi Internet Financial Reporting Pemerintah Daerah dan Implikasinya terhadap Akuntabilitas Laporan Keuangan Daerah. Jurnal Akuntansi Dan Bisnis, 17(2), 100109.

Gunawan, A. (2019). Pengaruh Kinerja Keuangan Terhadap Kualitas Informasi Internet Financial Reporting Dengan Kepemilikan Saham Publik Sebagai Variabel Moderasi. Jurnal Ekonomi Dan Sosial, 10(1), 1-10.

Khikmawati, I., \& Agustina, L. (2015). Analisis Rasio Keuangan Terhadap Pelaporan Keuangan Melalui Internet Pada Website Perusahaan. Accounting Analysis Journal, 4(1), 1-8.

Lidiyawati, L., \& Wulandari, R. (2015). The Effect of Ratio, Issuance of Stocks and Auditors' Quality toward the Timeliness of Financial Reporting on the Internet by Consumer Goods Sector Companies in Indonesia. Binus Business Review, 6(3), 439. $\mathrm{h}$

Narsa, I. M., \& Pratiwi, F. F. (2012). Internet Financial Reporting , Pengungkapan Informasi Website, Luas Lingkup Pelaporan Internet,.. Jurnal Ekonomi Dan Keuangan, 18(2), 259-273.

Pervan, I. (2006). Voluntary Financial Reporting on the Internet Analysis of the Practice of Stock-Market Listed Croatian and Slovene Joint Stock Companies. Financial Theory and Practice, 30(1), 1-27.

Pinto, I., \& Ng Picoto, W. (2016). Configurational analysis of firms' performance: Understanding the role of Internet financial reporting. 
Journal of Business Research, 69(11), 1-6.

Ratna Puri, D. (2013). Analisis FaktorFaktor yang Mempengaruhi Indeks Pelaporan Keuangan Melalui Internet. Jurnal Reviu Akuntansi Dan Keuangan, 3(1), 383-390.

Reskino, \& Sinaga, N. N. J. (2017). Kajian Empiris Internet Financial Reporting Dan Praktek Pengungkapan. Media Riset Akuntansi, Auditing Dan Informasi, 16(2), 161.

Rini, R. (2016). Penerapan Internet Financial Reporting untuk Meningkatkan Akuntabilitas Organisasi Pengelola Zakat. Jurnal Akuntansi Multiparadigma, 7(2), 288-306.

Rizqiah, R. N., \& Lubis, A. T. (2019). Penerapan Internet Financial Reporting (IFR) Pada Bank Umum Syariah Di Indonesia. Jurnal Akuntansi Dan Keuangan Islam, 5(1), 63-81.

Satria, R., \& Supatmi, . (2013). Reaksi Pasar Sebelum dan Sesudah Internet Financial Reporting. Jurnal Akuntansi Dan Keuangan, 15(2), 86-94.

Saud, I. M., Ashar, B., \& Nugraheni, P. (2019). Analisis Pengungkapan Internet Financial Reporting Perusahaan Asuransi-Perbankan Syariah Di Indonesia-Malaysia. Media Riset Akuntansi, Auditing \& Informasi, 19(1), 35-52.

Widari, P. putri, Saifi, M., \& Nurlaily, F. (2018). Analisis Internet Financial Reporting (IFR) (Studi Pada Perusahaan Manufaktur Yang Go Public di Indonesia, Singapura, dan Malaysia). Jurnal Administrasi Bisnis, 56(1), 100-109. 